\title{
Oestrus ovis in Ecuador: Importance in the Andean sheep farming
}

\author{
Gabriela Ortega-Muñoz ${ }^{1}$, Nivia Luzuriaga-Neira ${ }^{1,2}$, Richard Salazar-Silva ${ }^{1}$ and Richar Rodríguez-Hidalgo ${ }^{1,3}$
}

1. Department of Parasitology, Medicine, Veterinary and Zootechnic Faculty, Central University of Ecuador, EC170521, Quito, Ecuador; 2. Wildlife Conservation Research Unit, Central University of Ecuador, EC170521, Quito, Ecuador;

3. Parasitology Unit, Public Health and Zoonosis Research Institute, Central University of Ecuador EC170521, Quito, Ecuador.

Corresponding author: Richar Rodríguez-Hidalgo, e-mail: rrodriguez@uce.edu.ec

Co-authors: GO: gabyortega90@gmail.com, NL: nluzuriaga@uce.edu.ec, RS: rsalazar@uce.edu.ec

Received: 05-11-2018, Accepted: 25-02-2019, Published online: 14-04-2019

doi: 10.14202/vetworld.2019.522-526 How to cite this article: Ortega-Muñoz G, Luzuriaga-Neira N, Salazar-Silva R, Rodríguez-Hidalgo R (2019) Oestrus ovis in Ecuador: Importance in the Andean sheep farming, Veterinary World, 12(4): 522-526.

\begin{abstract}
Aim: This study aimed to determine the prevalence of Oestrus ovis in sheep meant for meat commercialization in the main slaughterhouse of the country.

Materials and Methods: Between October 2015 and December 2015, we assessed the occurrence of Oestrus myiasis in the main slaughterhouse localized in Quito. In total, 80 sheep heads were randomly inspected and necropsied. Larvae were removed from nasal cavities and paranasal sinuses and cleaned. ANOVA (generalized linear model) was used to estimate the relationship between sex, age, and place of origin and presence or absence of parasite larvae.
\end{abstract}

Results: Morphological identification confirmed that 19\% (15/80) of the examined animals were positive for Oestrus ovis; from the positive cases, $21 \%$ were young animals $<12$ months old. We found that statistical differences by animal sex, males, were most infested 93\% (14/15) than females 7\% (1/15). Larvae's L2 were more abundant than other stages (62 of the total 149). 14 of the infested animals were from the Andean places at $>2500$ meters above sea level (m.a.s.1.), and only one case from the coastal region at 250 m.a.s.l. with tropical environmental conditions.

Conclusion: Our results showed evidence of the presence of myiasis caused by $O$. ovis in Andean and coastal places in Ecuador and its adaptation to different environmental conditions from that reported previously in temperate regions from Europe and Africa.

Keywords: Ecuador, Ecuadorian highlands, oestrosis, Oestrus ovis, sheep.

\section{Introduction}

The sheep botfly Oestrus ovis (Diptera:Oestridae) is a cosmopolitan and obligate parasite in domestic and wild ruminants, mainly founding sheep and goats and eventually in some wild species [1,2] and humans [3-6]. Oestrosis causes low mortality. However, it produces high mobility in infected animals. Its signs and symptoms cause a negative effect on the herd, affecting long-term productivity with severe consequences on livestock production [7].

Oestrosis is present in different regions and habitats and has been reported worldwide, i.e., in the Mediterranean countries of Europe and Africa [8,9], Asia, and India [1,5]. In America, this parasite was found from California to the Patagonian regions, including Central America [10-12], as O. ovis activities appear to be accustomed to high temperatures (25$\left.28^{\circ} \mathrm{C}\right)$, strong solar radiation $\left(116-838 \mathrm{Wm}^{-2}\right)$, and a wide range of the relative humidity (65-85\%) [13].

Copyright: Ortega-Muñoz, et al. Open Access. This article is distributed under the terms of the Creative Commons Attribution 4.0 International License (http://creativecommons.org/licenses/ by/4.0/), which permits unrestricted use, distribution, and reproduction in any medium, provided you give appropriate credit to the original author(s) and the source, provide a link to the Creative Commons license, and indicate if changes were made. The Creative Commons Public Domain Dedication waiver (http:// creativecommons.org/publicdomain/zero/1.0/) applies to the data made available in this article, unless otherwise stated.
Besides, a high prevalence was found in tropical sub-humid sites where temperature, annual rainfall, and humidity were $26^{\circ} \mathrm{C}, 900 \mathrm{~mm}$, and $60-80 \%$, respectively [14]. Furthermore, in tropical regions, most oestrosis risks were documented in the sites with high temperatures and lower rainfalls [15]. So far, oestrosis has not been reported in Ecuador or the Ecuadorian highlands.

In spite of sheep bot fly being well-known by Andean Ecuadorian farmers, there is no information about their prevalence and incidence, or the economic losses caused by its presence. On the other hand, ovine livestock is becoming important in both highland and tropical regions; hence, the risk of infested animals by $O$. ovis must be evaluated.

This study aimed to determine the prevalence of Oestrus ovis in sheep meant for meat commercialization in the main slaughterhouse of the country.

\section{Materials and Methods}

\section{Ethical approval}

No ethical approval was needed for this study. None of the animals were used experimentally, and collection of the specimens was carried out after slaughter.

\section{Sample collection}

In total, 80 sheep heads were inspected at the Metropolitan Slaughterhouse in Quito (located at: 
Latitude -0.318794 and Longitude -78.563794) between October 2015 and December 2015. Around 300 sheep are slaughtered per month; hence, approximately $13 \%$ of ovine were selected randomly. Due to slaughterhouse's logistic, five sheep's heads were sampled each Tuesday and Thursday. Data from the sanitary certificate from each slaughtered animal were obtained to analyze geographical origin, sex, and age (Table-1). In addition, climate data were collected from the annual meteorological reports published by the National Institute of Meteorology and Hydrology [16].

\section{Sample processing}

At the slaughterhouse, heads were inspected as described by Bowman [17] (Figure-1). Briefly, the heads were dissected by cutting along their longitudinal axis to expose nasal cavities and paranasal sinuses, which were subsequently cleaned with distilled water. Larval samples were collected as described by Yilma and Dorchies [18].

\section{Larvae analysis}

Collected larvae were coded and placed in a container with $70 \%$ of ethanol caps and transported to the parasitology laboratory of the Veterinary Faculty of the Central University of Ecuador. Morphological identification was performed by direct observation using a stereoscope and dichotomous keys; the larvae were identified as described by Moya et al., [19].

\section{Statistical analysis}

Associations between the presence of the parasite and animal origin, sex, and age were estimated using ANOVA (generalized linear model) with binomial distribution in $\mathrm{R}$ statistic free software version 3.2, package MASS [20]. We consider dependent variable the presence or absence $(0=$ absence and $1=$ presence $)$, and the independent variables: Animal origin $(n=7)$, sex $(\mathrm{M}=$ male and $\mathrm{H}=$ female $)$, age $(<1,>1$-year-old $)$, and age of the sheep were recorded from the certificate sanitary.

\section{Results}

From 80, heads inspected 15 (19\%) were infested with $O$. ovis larvae. Moreover, among positive cases, males were most infected than females 14 (93\%) and 1 case $(7 \%)$, respectively. 14 sheep came from Andean region farms located at $>2500$ meters above sea level (m.a.s.l.). with low temperatures and dry areas and one infested animal came from the coastal area at 50 m.a.s.l. with high temperatures and humidity annual averages (Table-1). Geographical location of positive cases is graphed in Figure-2, i.e., 53.3\% from Ambato, 20\% from Salcedo, 20\% from Saquisilí, Latacunga, and Rumiñahui at the highlands, and 6.6\% from Guayaquil in the Coastal region (Figure-2). Most positive cases were from Andean sites with minimal differences in temperature $\left(14-15^{\circ} \mathrm{C}\right)$ and humidity (75-76\%) annual averages.

No statistical differences were found for age and origin; however, animals aged 3 months- 1 year had a

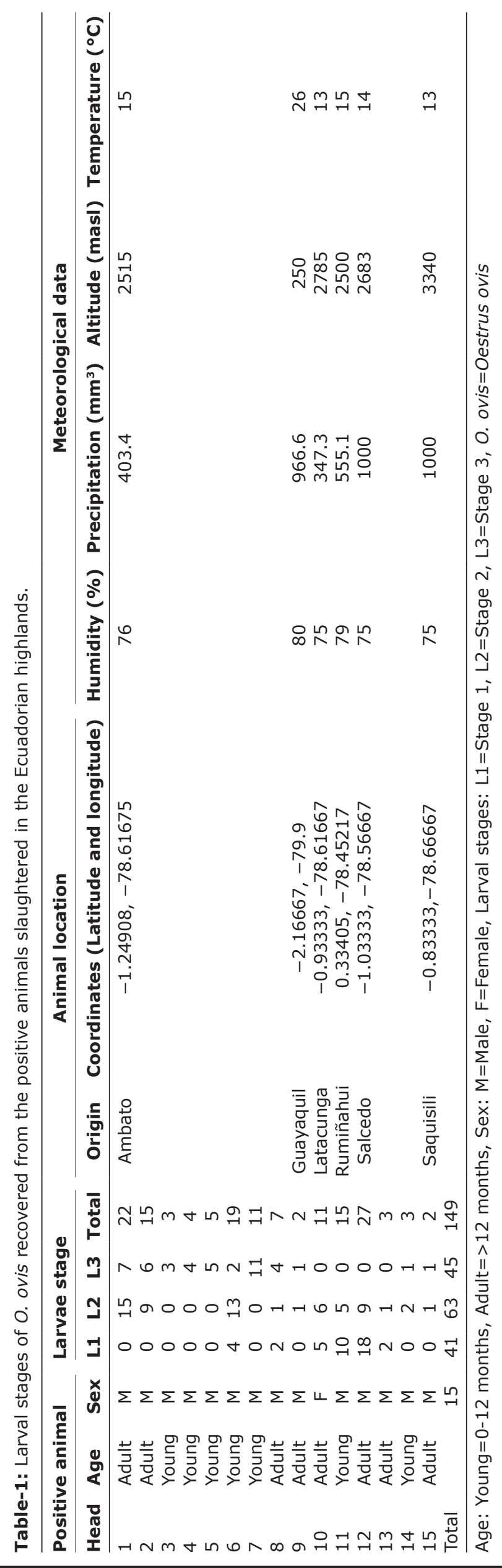

Veterinary World, EISSN: 2231-0916 
higher percentage of infestation $(21 \%)$ than animals older than 1 year $(17 \%)$. Statistical differences $(<0.05)$ were found for sex, i.e., males, with $23 \%(14 / 15)$, while females reached 5\% (1/15) (ANOVA: $\mathrm{F}_{40.8}=1$, $\mathrm{p}=0.043)($ Table-2). On the other hand, in total, 149 larvae (42\% [L2]; $30 \%$ [L3]; and 28\% [L]) were collected from 15 infected heads (Table-1). The mean larval burden per sheep was 5.4 larvae. The average larvae stages did not differ ( $p>0.05)$ among groups ( $\mathrm{L} 1=2.73 \pm 5.07 ; \mathrm{L} 2=4.20 \pm 5.07$, and $\mathrm{L} 3=3.00 \pm 3.20$ ).

\section{Discussion}

Our findings showed $19 \%$ of the prevalence of $O$. ovis in the highlands of Ecuador. Previously, other studies carried out in South America showed a prevalence of oestrosis of $13.7 \%$ and $16.9 \%$ in Brazil [10,21], $60 \%$ in Chile [12], and 33.4\% in Mexico [14]. All these studies were carried out in different geographical and ecologic zones with different climatic conditions to our study.
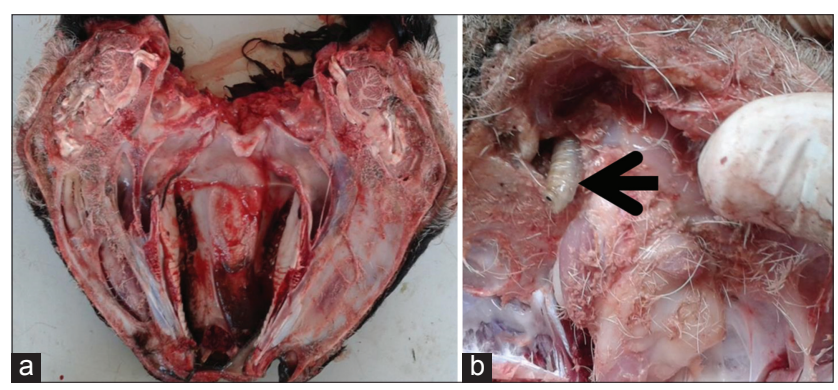

Figure-1: Examination method of the presence of Oestrus ovis in individuals destined for slaughter, in a public slaughterhouse of the Metropolitan district of Quito. $a=$ cross section of the head; $b=$ extraction of Oestrus ovis.
According to Abo-Shehada et al. [22], Cepeda-Palacios and Scholl [13], Papadopoulos et al. [23], and ParedesEsquivel et al. [24], the $O$. ovis flneeds specific conditions for development, i.e., when temperatures are between 25 and $28^{\circ} \mathrm{C}$ and the solar radiation is between 116 and $838 \mathrm{Wm}^{-2}$ and these conditions are mainly present in temperate regions in the spring and summer season. In addition, the authors documented higher oestrosis risk in sites with higher temperature and lower rainfall [25]. Ecuador is a tropical country where different ecological niches are present due to the Andean Cordillera. Most infested animals stem from the highlands, where temperatures and solar radiations are unlike those from temperate regions [16].

In our study, no statistic difference $(\mathrm{p}>0.05)$ was found between the age and sex of animals that were oestrosis positive, probably due to the random selection at the slaughterhouse or a similar trend in the management in sheep livestock. Other studies reported different results and mentioned that adults or even females are more affected than young or male sheep $[10,26,27]$. Unexpectedly, one positive animal came from the coastal region where myiasis is supposed to be absent; however, further studies are needed to demonstrate the prevalence and importance of oestrosis in the tropical areas of Ecuador.

The number of larvae and larval stages found in this study were near to Caracappa et al. [27], i.e., on average 5.4 larvae per infested animal, in Sicily-Italy. In another study carried out on the Balearic Islands, a higher percentage of L1 was reported [24]. Although all these which indicate

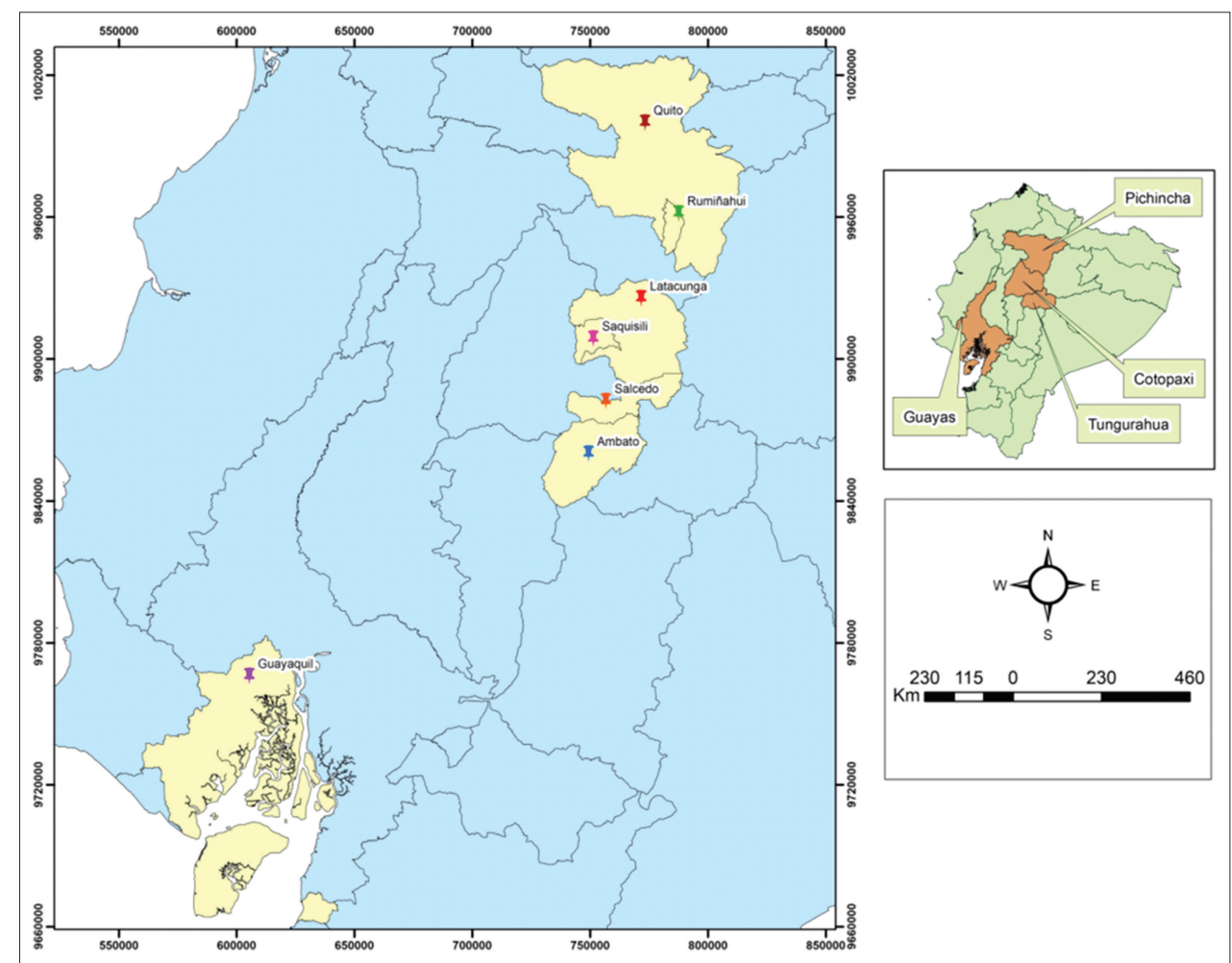

Figure-2: The geographical location of the places of the origin sheep infected with Oestrus ovis parasite, in the Coastal and Andean regions of the Ecuador. 
Table-2: Differences of sex, age, and site on the presence-absence of $O$. ovis in sheep $(n=80)$ from six sites of Ecuador. The results are from GLM with binomial distribution ( $95 \%$ of probability).

\begin{tabular}{lccccc}
\hline Coefficients & DF & DR & RD & F & p<0.05 \\
\hline Sex & 1 & 40.791 & 73.133 & 40.791 & $0.04342 *$ \\
Age & 1 & 0.0191 & 68.994 & 0.0191 & 0.89010 \\
Origin place & 7 & 33.811 & 65.613 & 0.4830 & 0.84765
\end{tabular}

Origin places: Ambato, Guayaquil, Mejía, Latacunga, Rumiñahui, Salcedo, and Saquisilí. Males sheep were most infected than females $(p<0.05)$ *show statistical differences insignificant level of 0.05 . DF=Degree of freedom, $\mathrm{DR}=$ Deviance residual, $\mathrm{RD}=$ Residual degree, $\mathrm{F}=\mathrm{F}$ statistic, $P=\mathrm{p}$-value. Age: Young $=0-12$ months, Adult $=>12$ months, sex: $M=$ Male. $G L M=$ Generalized linear model, $O$. ovis=Oestrus ovis

an active flying activity of adult $O$. ovis flies on the sites with Mediterranean climate, our results demonstrated fly activity at the high altitudes of Andes (>2500 m.a.s.1.), where only two seasons are evident, i.e., rainy (October-April) and dry season (May-September) according to the reported case published by Hoyer et al. [28]. Moreover, sheep livestock is important in the Andean Highlands from Colombia to Argentina, where the population was estimated to be around 57 million sheep [29]; hence, it is most likely that this parasite is affecting farms and causing huge loses not yet estimated in livestock.

According to our observation, this study is the first record in sheep which shows the evidence and importance of oestrosis in environments $>2500$ m.a.s.l. at Andean region in South America. Most of the results found on the epidemiology of $O$. ovis were reported from temperate regions such as Spain, Italy, Turkey, and France $[8,18,26,27]$, where infested cases are seen at low altitudes (e.g., 250-1725 m.a.s.l.) and temperatures $>30^{\circ} \mathrm{C}$ in the summer season. This, in contrast with our study region, shows that $O$. ovis fly is adapted to high altitudes and dry habitats.

\section{Conclusion}

Our study demonstrates the presence of $O$. ovis at a high altitude in six different locations in Ecuador; five of them from the Andean Region, and one from the Coastal Region where tropical environmental conditions predominant. Furthermore, studies are recommended to assess the prevalence, incidence rate, risk factors, and spatial-temporal distribution in Andean and Tropical regions in Ecuador. Although the presence of the disease has been known by farmers, the understanding of $O$. ovis epidemiology should be improved.

\section{Authors' Contributions}

NL and RR conceived the study and participated in its design and coordination. RS and GO carried out the sampling and the analysis. RR and NL wrote the manuscript, and all authors read and approved the final manuscript.

\section{Acknowledgments}

This project is supported financially by the "Universidad Central del Ecuador" (Grant No. N42). We also thank the "Empresa Metropolitana de Rastro Quito" for authorization of the study and logistical support during necropsies. We thank the "Laboratorio de Parasitología de Facultad de Medicina Veterinaria y Zootecnia" for logistical support during sample processing. Thanks to Jef Brandt for his comments and suggestions on the manuscript.

\section{Competing Interests}

The authors declare that they have no competing interests.

\section{Publisher's Note}

Veterinary World remains neutral with regard to jurisdictional claims in published map and institutional affiliation.

\section{References}

1. Sánchez, A., Caparrós, N., Ostrowski, S., Sarasa, M. and Pérez, J.M. (2017) Oestrosis in Asiatic ibex (Capra sibirica): A case report and molecular characterization of larvae. Vet. Parasitol., 236: 55-57.

2. Barroso, P., Ruiz-de-Ybanez, R., Martinez-Carrasco, C., Gens, M.J., Escribano, F., Sanchez, A. and Perez, J.M. (2017) First report of oestrosis in aoudad from Southeastern Spain. Parasitol. Res., 116(7): 2053-2055.

3. Akesbi, J. and Nordmann, J.P. (2014) Oestrus ovis larva infection presenting as conjunctivitis after a trip to Israel. $J$. Fr. Ophtalmol., 37(7): 588.

4. Cameron, J.A., Shoukrey, N.M. and al-Garni, A.A. (1991) Conjunctival ophthalmomyiasis caused by the sheep nasal botfly (Oestrus ovis). Am. J. Ophthalmol., 112(3): 331-334.

5. Fasih, N., Qaiser, K.N., Bokhari, S.A., Jamil, B. and Beg, M.A. (2014) Human ophthalmomyiasis externa caused by the sheep botfly Oestrus ovis: A case report from Karachi, Pakistan. Asian. Pac. J Trop. Biomed., 4(10): 835-837.

6. Fernandez, L.S., Hernandez-Porto, M., Tinguaro, V. and Fernandez, M.L. (2017) Ophthalmomyiasis and nasal myiasis by Oestrus ovis in a patient from the Canary Islands with uncommon epidemiological characteristics. Enferm. Infecc. Microbiol. Clin., 35(7): 461-462.

7. Sotiraki, S. and Hall, M.J.R. (2012) A review of comparative aspects of myiasis in goats and sheep in Europe. Small Rumin. Res., 103(1): 75-83.

8. Alcaide, M., Reina, D., Frontera, E. and Navarrete, I. (2005) Epidemiology of Oestrus ovis (Linneo, 1761) infestation in goats in Spain. Vet. Parasitol., 130(3-4): 277-284.

9. Biggs, H.C., McClain, E., Muller, G.L., Anthonissen, M. and Hare, K.M. (1998) A prediction model for strike in the sheep nasal fly, Oestrus ovis, in Namibia. Prev. Vet. Med., 33(1-4): 267-282.

10. Silva, B.F., Machado, G.P., Izidoro, T.B. and Amarante, A.F. (2013) Prevalence of Oestrus ovis (Diptera: Oestridae) in sheep from the Sao Paulo central region, Brazil. Rev. Bras. Parasitol. Vet., 22(1): 18-21.

11. Silva, B.F.D., Bassetto, C.C. and Amarante, A.F.T. (2012) Epidemiology of Oestrus ovis (Diptera: Oestridae) in sheep in Botucatu, state of São Paulo. Rev. Bras. Parasitol. Vet., 21(4): 386-390.

12. Hidalgo, A., Palma, H., Oberg, C. and Fonseca-Salamanca, F. (2015) Oestrus ovis infection of grazing sheep during summer in southern Chile. Pesqui. Vet. Bras., 35(6): 497-500.

13. Cepeda-Palacios, R. and Scholl, P.J. (2000) Factors affecting 
the larvipositional activity of Oestrus ovis gravid females (Diptera: Oestridae). Vet. Parasitol., 91(1-2): 93-105.

14. Murguia, M., Rodriguez, J.C., Torres, F.J. and Segura, J.C. (2000) Detection of Oestrus ovis and associated risk factors in sheep from the central region of Yucatan, Mexico. Vet. Parasitol., 88(1-2): 73-78.

15. Fonseca, O., Moya, V.M., Montano, D.D., Centelles, Y., Percedo, M.I. and Alfonso, P. (2018) Spatial modeling of oestrosis in sheep in Guantánamo province, Cuba. Small Rum. Res., 164: 32-38.

16. INAMHI. (2017) Publicaciones Meteorologicas. Anuario meteorologico No. 53. INAMHI. Available from: http://www. serviciometeorologico.gob.ec Last accessed on 19-10-2018.

17. Bowman, D.D. (2011) Georgis' Parasitology for Veterinarians. $9^{\text {th }}$ ed. Elsevier, Barcelona.

18. Yilma, J.M. and Dorchies, P. (1991) Epidemiology of Oestrus ovis in Southwest France. Vet. Parasitol., 40(3-4): 315-323.

19. Moya, V.M., Rodríguez, D., Alfonso, P., Pérez, J.M. and Olivares, J. (2012) Morfometría de larvas de Oestrus ovis (Diptera: Oestridae) de ovinos, en Cuba. Rev. Salud. Anim., 34(2): 184-187.

20. Venables, W. N. \& Ripley, B. D. (2002) Modern Applied Statistics with S. Fourth Edition. Springer, New York. ISBN 0-387-95457-0.

21. Carvalho, R.S., Ruivo, M.A., Colli, M.H.A., Pereira, V., Martinez, A.C., Mazzucatto, B.C., Cruz, B.C., Maciel, W.G., Felippelli, G., Teixeira, W.F.P., Soares, V.E., Costa, A.J.D. and Lopes, W.D.Z. (2015) Occurrences of Oestrus ovis parasitism in necropsied sheep in the Umuarama microregion, Paraná, Brazil. Rev. Bras. Parasit. Vet., 24(3): 370-374.

22. Abo-Shehada, M.N., Arab, B., Mekbel, R., Williams, D. and Torgerson, P.R. (2000) Age and seasonal variations in the prevalence of Oestrus ovis larvae among sheep in northern Jordan. Prev. Vet. Med., 47(3): 205-212.

23. Papadopoulos, E., Chaligiannis, I. and Morgan, E.R. (2010) Epidemiology of Oestrus ovis L. (Diptera: Oestridae) larvae in sheep and goats in Greece. Small Rumin. Res., 89(1): 51-56.

24. Paredes-Esquivel, C., Rio, R.D., Monerris, M., Marti, T., Borrás, D. and Miranda, M.A. (2009) High prevalence of myiasis by Oestrus ovis in the Balearic Islands. Parasite, 16(4): 323-324.

25. Papadopoulos, E., Prevot, F., Jacquiet, P., Duranton, C., Bergeaud, J.P., Kalaitzakis, E. and Dorchies, P. (2001) Seasonal variation of Oestrus ovis-specific antibodies in sheep and goats mixed flocks in Greece. Vet. Parasitol., 95(1): 73-77.

26. Arslan, M.O., Kara, M. and Gicik, Y. (2009) Epidemiology of Oestrus ovis infestations in sheep in Kars province of North-Eastern Turkey. Trop. Anim. Health Prod., 41(3): 299-305.

27. Caracappa, S., Rilli, S., Zanghi, P., Di Marco, V. and Dorchies, P. (2000) Epidemiology of ovine oestrosis (Oestrus ovis Linne 1761, Diptera: Oestridae) in Sicily. Vet. Parasitol., 92(3): 233-237.

28. Hoyer, P., Williams, R.R., Lopez, M. and Cabada, M.M. (2016) Human nasal myiasis caused by Oestrus ovis in the highlands of Cusco, Peru: Report of a case and review of the literature. Case Rep. Infect. Dis., Vol. 2016, Article ID 2456735 .

29. Cardellino, R.C. and Mueller, J.P. (2009) Fiber production and sheep breeding in South America. Proc. Assoc. Adv. Anim. Breed. Genet., 18: 366-373. 